\title{
Transcription Factor SOX-4
}

National Cancer Institute

\section{Source}

National Cancer Institute. Transcription Factor SOX-4. NCI Thesaurus. Code C112921.

Transcription factor SOX-4 (474 aa, $\sim 47 \mathrm{kDa}$ ) is encoded by the human SOX4 gene. This protein plays a role in both $\mathrm{T}$-cell differentiation and transcriptional activation. 